\title{
Practices of Niruha Vasti in Low back pain from an Academic Hospital of Kerala - An observational study
}

\author{
Research Article
}

\section{Shabna $\mathbf{P}^{1^{*}}$, Jigeesh $\mathbf{P} \mathbf{P}^{2}$, Subin $\mathbf{V} \mathbf{R}^{3}$}

1. PG Scholar, 2. Professor, 3. Assistant Professor, Department of Panchakarma,VPSV Ayurveda College Kottakkal India.

\begin{abstract}
Introduction: Niruha Vasti plays a major role when compared to Anuvasana, because of its variety of drug combinations and utility in a wide range of clinical conditions. Many formulations of Vasti are, in practice which came from the clinical experiences of eminent physicians and from researches. There is a deficit of baseline data regarding the current practices of Niruha Vasti in LBP and the preparation of which may help to prioritize the topics for further research. Materials and Methods: The study design was prospective cross-sectional observational study and sample included all the patients admitted in VPSV Ayurveda College Hospital, Kottakkal during JanuaryDecember 2018, presented with LBP and posted for Niruha Vasti. Study tool used was a Data collection form which was prepared from available literatures. Data was verified, analyzed and presented with the help of tables and charts. Statistical analysis was done by Microsoft office 2016 and IBM SPSS Statistics version 16. Observation and Results: Total 141 patients were observed and among them 474 Vasti done in 174 schedules and 16 different types of Vasti were used. Vaitarana Vasti, Madhutailika Vasti, Kshira Vasti, Ruksha Vasti, Erandamuladi Vasti and Grdhrasihara Vasti are the major Vasti prescribed in LBP patients. Conclusion: There are certain characteristic patterns in the practice of Niruha Vasti administered in cases of Low Back Pain.
\end{abstract}

Key Words: Kerala, Low back pain, Niruha Vasti, Observational study, Treatment profile, Cross-sectional survey.

\section{Introduction}

Among Panchakarma, Vasti is considered as the supreme therapeutic modality, as it radically weeds out the morbid Vata, which is responsible for the pathogenesis of various diseases and movement of other Dosha, Dhatu and Mala within the body (1). Even though Vasti is specially indicated for diseases originated from the pakvasaya (lower part of the gut), it can also cure diseases affecting the head by different formulations. In practice also, it is very commonly selected for the management of almost all diseases of current scenario irrespective of age, gender or system. Vasti is one of the most important areas of research and several studies on Vasti are being conducted in postgraduate and other research centres. Most of the studies have focused on the efficacy of different Vasti in various conditions. Niruha Vasti plays a major role when compared to Anuvasana, because of its variety of drug combinations and utility in a wide range of clinical conditions

* Corresponding Author:

\section{Shabna $\mathbf{P}$}

\section{PG Scholar,}

Department of Panchakarma,

VPSV Ayurveda College,

Kottakkal. India.

Email Id: shabnapusman@gmail.com
Low Back Pain (LBP) is one of the most frequently encountered conditions in clinical practice, referred to as the $2^{\text {nd }}$ frequent reason for visiting a doctor (2). Up to 84percent of adults have LBP at some time in their lives (3). Although there is no evidence that LBP prevalence has increased, reported disability and absence from work due to LBP have increased significantly in the last thirty years (4). It is not a specific disease, but rather a complaint that may be caused by a large number of underlying problems of varying levels of seriousness. It can have major adverse impacts on the quality of life and function. In Ayurveda, LBP has been explained as a symptom of several pathological states of Dosha by different authors. The terms like Trikasula, Katisula, Pristasula, Gridhrasi, Katigraha refers to similar conditions $(5,6)$. Pakvasaya is the location of vitiated Dosha and hence Vasti has been advocated as the treatment (7).

Kerala is well acknowledged as one of the premier locations where Ayurveda flourishes. Keraleeya Ayurveda is a most sought therapy by both patients and healthy and possess a considerable customer base. Innumerable clinics and hospitals prevail in this Indian state and most Panchakarma therapies are practiced here commonly. Data taken from VPSV Ayurveda College Kottakkal, a pioneer Ayurveda institution of Kerala showed that an average of 200 Niruha Vasti is being done per month out of which $10 \%$ done for LBP. Previous studies have focused on the efficacy of different Vasti formulations and proved to be effective in various clinical conditions. There are no data 
Shabna P et.al., Practices of Niruha Vasti in Low back pain from an Academic Hospital of Kerala - An observational study

regarding the current practices of Niruha Vasti in LBP It is not known that which Vasti is commonly prescribed in LBP and whether pathology of LBP influence the selection of Vasti. No data are available about the types of Vasti practiced in LBP, their demographic variables, influential factors for selection of Vasti and clinical predictors of outcome of Vasti; data about the magnitude of complications is also lacking. Hence, this study has been carried out to document the clinical practices of Niruha Vasti in LBP patients at the VPSV Ayurveda College Hospital, Kottakkal during 2018.

\section{Materials and methods}

This study was conducted as a prospective cross-sectional observational study with ethical clearance obtained from the Institutional Ethics Committee of V.P.S.V Ayurveda College, Kottakkal. (Approval no: Ref IEC/CL/17/17; dated 27/04/2017). Data collection started on January $1^{\text {st }}, 2018$ and was completed on December 31st 2018. The sample included all the participants admitted in VPSV Ayurveda College Hospital, Kottakkal during January-December 2018, who had presented with LBP and were posted for Niruha Vasti. Written informed consents were obtained from all participants. The data were collected from the records available in the hospital like electronic data, case sheets and the patients were also interviewed. The information collected were entered in a data collection form. The pro forma contained sociodemographic information, medical history, details of clinical examinations, available laboratory results, investigations and diagnosis. The details of Niruha Vasti, including the formulation with dose of each content, schedule, pattern of doing, placement of Niruha Vasti in the course of treatment, diet during Niruha Vasti, events (Complications of Niruha Vasti) if any, were also recorded.

Stored data were cleaned, duplicate data entry and missing data were checked prior to statistical analysis. It was done by Microsoft office 2016 and IBM SPSS Statistics version 16. All categorical variables were expressed as frequencies and percentages, and continuous variables were expressed as mean with standard deviation or median with range. Dummy tables were prepared for presentation of analysed data.

\section{Results}

Data of a total of 141 participants were analysed during the 12 months study period. Among 141 participants 29 participants were posted for two schedules of the Vasti, 2 participants had 3 schedules of Vasti and the remaining 110 participants had one schedule of Vasti in the total course of treatment. Thus, it was estimated that a total of 174 schedules were there in the study period. A total of 474 Vasti were done in these schedules. Out of 174 schedules, $14.9 \%$ had a Yoga Vasti pattern; 23\% had done as single Vasti; and some other patterns followed at $62.1 \%$. Karma Vasti \& Kala Vasti were not seen prescribed for LBP during the study period (table 1)
Table 1. Distribution of Niruha Vasti according to pattern

\begin{tabular}{|c|c|c|}
\hline Pattern & Frequency & Percent \\
\hline Karma Vasti \& Kala Vasti & 0 & 0.0 \\
\hline Yoga Vasti & 26 & 14.9 \\
\hline Single Vasti & 40 & 23.0 \\
\hline Other & 108 & 62.1 \\
\hline Total & 174 & 100 \\
\hline
\end{tabular}

Among 108 schedule which had some other patterns of Niruha, 28 had followed the pattern of doing 3 Kashaya Vasti consecutively and this pattern was seen in schedule of Vaitarana Vasti and Ruksha Vasti. 7 followed the schedule of two consecutive Kashaya Vasti and another 7 followed two Kashaya Vasti with rest in between them; the patterns two Matra Vasti followed by three consecutive Kashaya Vasti and three Kashaya Vasti with rest in between each Vasti were seen in 6 schedules each. Five and seven consecutive Kashaya $V a s t i$ were observed in 5 schedules each. Similarly, few other patterns have also been seen with one schedule. $24.1 \%$ had some other patterns which were done in single cases only (table 2).

Table 2. Unclassified patterns of Niruha followed

\begin{tabular}{|l|c|c|}
\hline Pattern & Frequency & Percent \\
\hline$k v k v k v$ & 22 & 20.4 \\
\hline$k v k v$ & 7 & 6.5 \\
\hline$k v$ rest $k v$ & 7 & 6.5 \\
\hline$m v m v k v k v k v$ & 6 & 5.6 \\
\hline$k v$ rest $k v r e s t k v$ & 6 & 5.6 \\
\hline$k v k v k v k v k v$ & 5 & 4.6 \\
\hline$k v k v k v k v k v k v k v$ & 5 & 4.6 \\
\hline$m v m v k v m v k v$ & 4 & 3.7 \\
\hline$k v m v k v$ & 3 & 2.9 \\
\hline$k v m v)(k v m v)(k v m v)(k v m v)$ & 3 & 2.9 \\
$(k v m v)$ & 2 & 1.9 \\
\hline$m v k v k v$ & 2 & 1.9 \\
\hline$m v m v k v k v m v$ & 2 & 1.9 \\
\hline$m v k v m v k v k v$ & 2 & 1.9 \\
\hline$m v k v k v k v$ & 2 & 1.9 \\
\hline$m v m v k v r e s t k v$ & 2 & 1.9 \\
\hline$m v k v m v k v m v k v$ & 2 & 1.9 \\
$k v k v k v k v$ & 26 & 24.1 \\
\hline Other & 108 & 100.0 \\
\hline Total & &
\end{tabular}

(NB: $\boldsymbol{k v}$-Kashaya Vasti; $\boldsymbol{m} \boldsymbol{v}$ - Matra Vasti; ( $\boldsymbol{k v} \boldsymbol{m} \boldsymbol{v})$ Kashaya Vasti and Matra Vasti in bracket indicates both done on same day)

It was observed that among 474 Niruha Vasti, 16 types of Vasti were done. There were 106 Kshara vaitarana Vasti; 84 were Madhutailika Vasti; 64 were Ruksha Vasti; 47 were Grdhrasihara Vasti; 45 were Erandamuladi Vasti; 18 were Kshira vaitarana Vasti; 17 were Mustadi yapana Vasti; 10 were Dvigunaprasrta Vasti; 3 each were Erandamuladi yapana Vasti, Manchishtadi kshara Vasti and Udavartahara Vasti respectively; 2 were Doshahara Vasti and 1 each were Kledahara Vasti, Kshara Vasti and Yapana Vasti respectively (table 3 ). 
Table 3. Distribution of various types of Vasti

\begin{tabular}{|c|l|c|c|}
\hline No & \multicolumn{1}{|c|}{ Vasti } & Frequency & Percent \\
\hline 1 & Kshara vaitarana Vasti & 106 & 22.4 \\
\hline 2 & Madhutailika Vasti & 84 & 17.7 \\
3 & Kshira Vasti & 69 & 14.6 \\
\hline 4 & Ruksha Vasti & 64 & 13.5 \\
\hline 5 & Grdhrasihara Vasti & 47 & 9.9 \\
\hline 6 & Erandamuladi Vasti & 45 & 9.5 \\
\hline 7 & Kshira vaitarana Vasti & 18 & 3.8 \\
\hline 8 & Mustadi yapana Vasti & 17 & 3.6 \\
\hline 9 & Dvigunaprasta Vasti & 10 & 2.1 \\
10 & Erandamuladi yapana Vasti & 3 & 0.6 \\
11 & Manchishtadi kshara Vasti & 3 & 0.6 \\
12 & Udavartahara Vasti & 3 & 0.6 \\
\hline 13 & Doshahara Vasti & 2 & 0.4 \\
14 & Kledahara Vasti & 1 & 0.2 \\
\hline 15 & Kshara Vasti & 1 & 0.2 \\
16 & Yapana Vasti & 1 & 0.2 \\
\hline & Total & $\mathbf{4 7 4}$ & $\mathbf{1 0 0 . 0}$ \\
\hline
\end{tabular}

The distribution of different Vasti among participants has shown that Madhutailika Vasti was done in 42 participants and Kshara vaitarana Vasti among 41 participants. Kshira Vasti, Erandamuladi Vasti and Grdhrasihara Vasti were done among 24, 23, and 22 participants respectively. Ruksha Vasti was done in 17 participants, Mustadi yapana Vasti in 6 participants and Kshira vaitarana Vasti among 5 participants. Dvigunaprasrta Vasti and Doshahara Vasti were done among 2 participants each. Erandamuladi yapana Vasti, Manchishtadi kshara Vasti, Udavartahara Vasti, Kledahara Vasti, Kshara Vasti and Yapana Vasti were done only in one patient each (table 4)

\section{Table 4. Distribution of different types of Vasti among participants}

\begin{tabular}{|c|l|c|c|}
\hline No & \multicolumn{1}{|c|}{ Vasti } & Frequency & Percent \\
\hline 1 & Madhutailika Vasti & 42 & 29.8 \\
\hline 2 & Kshara vaitarana Vasti & 41 & 29.1 \\
\hline 3 & Kshira Vasti & 24 & 17 \\
\hline 4 & Erandamuladi Vasti & 23 & 16.3 \\
5 & Grdhrasihara Vasti & 22 & 15.6 \\
\hline 6 & Ruksha Vasti & 17 & 12.1 \\
7 & Mustadi yapana Vasti & 6 & 4.3 \\
\hline 8 & Kshira vaitarana Vasti & 5 & 3.5 \\
\hline 9 & Dvigunaprasrta Vasti & 2 & 1.4 \\
10 & Doshahara Vasti & 2 & 1.4 \\
11 & Erandamuladi yapana Vasti & 1 & 0.7 \\
\hline 12 & Manchishtadi kshara Vasti & 1 & 0.7 \\
13 & Udavartahara Vasti & 1 & 0.7 \\
\hline 14 & Kledahara Vasti & 1 & 0.7 \\
15 & Kshara Vasti & 1 & 0.7 \\
16 & Yapana Vasti & 1 & 0.7 \\
\hline
\end{tabular}

Among the total 174 schedules, 84 (48.3\%) were placed as the last treatment, $74(42.5 \%)$ were done in the middle of treatment course and 16 were placed as initial treatment (table 5).

Table 5. Placement of Vasti schedule in the total course of treatment

\begin{tabular}{|c|c|c|}
\hline $\begin{array}{c}\text { Placement of Vasti } \\
\text { schedule }\end{array}$ & Frequency & Per cent \\
\hline Starting & 16 & 9.2 \\
\hline Middle & 74 & 42.5 \\
\hline End & 84 & 48.3 \\
\hline Total & 174 & 100 \\
\hline
\end{tabular}

In the 16 Vasti schedules which were done as initial treatment, 10 were Vaitarana Vasti and 6 were Ruksha Vasti. The Vasti schedules placed in the middle of treatment course were, 20 Vaitarana Vasti schedules, 14 Madhutailika Vasti, 13 Erandamuladi Vasti, 11 Ruksha Vasti and 7 Grdhrasihara Vasti. 2 Kshira Vasti schedules also placed in the middle of the treatment course. One schedule of each Udavartahara Vasti, Mustadi yapana Vasti, Manchishtadi kshara Vasti, Kshara Vasti, Kledahara Vasti, Doshahara Vasti and Dvigunaprasrta Vasti were also placed in the middle of the treatment course. Among the 84 Vasti schedules done as the last treatment, $28.6 \%$ were Madhutailika Vasti, 22.6\% were Kshira Vasti, 19.1\% were Vaitarana Vasti and 13.1\% were Grdhrasihara Vasti. $8.3 \%$ of Erandamuladi Vasti and $4.8 \%$ of Mustadi yapana Vasti were done as last treatment. $1.2 \%$ each, Dvigunaprasrta Vasti, Erandamuladi yapana Vasti and Ruksha Vasti were also done at the end treatment in the total treatment course.

Among the 106 Vaitarana Vasti, 64 were done using Dhanyamla and Gomutra was used in 39 Vasti. Instead of Dhanyamla or Gomutra, Kulattha gokshura kashaya $(240 \mathrm{ml})$ was used in 3 Vasti.

Among the 84 Madhutailika Vasti done for LBP, Dhanvantaram taila was used in majority of Vasti (43) and Sahacharadi taila was used in 27 Vasti. In 9 Vasti, Tila taila was used, 4 were done using Pippalyadi anuvasana taila and in one Vasti Sinduvara eranda taila was used.

In this study it was noted that, among the 69 Kshira Vasti, 46 were done using Panchatiktaka Kshira kvatha all with a dose $240 \mathrm{ml}$. Bala yashti asvagandha kshira kvatha were used in 22 Vasti and one Vasti was done with Dhanvantaram kshira kvatha.

\section{Table 6. Different combinations of Ruksha Vasti}

\begin{tabular}{|c|l|c|c|}
\hline No & \multicolumn{1}{|c|}{ Combinations } & Count & $\%$ \\
\hline 1 & $\begin{array}{l}\text { Amrtottaram kashaya }-300 \mathrm{ml} ; \\
\text { Vaisvanara churnam-30 gm }\end{array}$ & 41 & 64.1 \\
\hline 2 & $\begin{array}{l}\text { Amrtottaram kashaya }-480 \mathrm{ml} ; \\
\text { Vaisvanara churnam }-30 \mathrm{gm}\end{array}$ & 12 & 18.8 \\
\hline 3 & $\begin{array}{l}\text { Gandharvahastadi Kashaya - 300 } \\
\text { ml; Vaisvanara churnam - 30 gm }\end{array}$ & 11 & 17.2 \\
\hline
\end{tabular}

Among the 64 Ruksha Vasti, 64.1\% were done, using $300 \mathrm{ml}$ Amrtottaram kashaya and $30 \mathrm{gm}$ Vaisvanara churnam. $480 \mathrm{ml}$ of Amrtottaram Kashaya was used in $18.8 \%$ of Vasti. In $17.2 \%$ Vasti, $300 \mathrm{ml}$ Gandharvahastadi kashaya was used instead of Amrtottaram Kashaya (table 6).

The standard combination of Grdhrasihara Vasti which is followed at VPSV Ayurveda college Kottakkal, is Saindhava - 15 gm; Honey - $120 \mathrm{ml}$; Taila and Ghrta according to condition - $75 \mathrm{ml}$ each; Kalka prepared using Madana, Vacha, Pippalimula , Ajamoda, Satapushpa, Yashti, Devataru, Indrayava, Sarshapa - 30 gm; Kashaya prepared using Vasa, Asmabheda, Punarnava, Dhanyaka, Eranda, Dasamula, Bala, Murva, Yava, Kola, Sati, Kulattha, Vilva, Kiratatikta - $480 \mathrm{ml}$; Ikshurasa - $75 \mathrm{ml}$; Ajamamsarasa - $30 \mathrm{ml}$; Gomutra $-75 \mathrm{ml}$ and Milk -75 $\mathrm{ml}$. 
Shabna P et.al., Practices of Niruha Vasti in Low back pain from an Academic Hospital of Kerala - An observational study

\begin{tabular}{|c|c|c|c|}
\hline No & Category & Frequency & Percentage \\
\hline 1 & Sahacharadi taila & 218 & 53.7 \\
\hline 2 & Dhanvantaram taila & 98 & 24.1 \\
\hline 3 & Pippalyadi anuvasana taila & 24 & 5.9 \\
\hline 4 & Madhuyashtyadi taila & 18 & 4.4 \\
\hline 5 & Tila taila & 12 & 3.0 \\
\hline 6 & Mahanarayana taila & 11 & 2.7 \\
\hline 8 & Satahvadi taila & 7 & 1.7 \\
\hline 9 & Karpasasthyadi taila & 5 & 1.2 \\
\hline 10 & Sinduvara eranda taila & 4 & 1 \\
\hline 7 & Panchamla taila & 3 & 0.7 \\
\hline 11 & Chinchadi taila & 3 & 0.7 \\
\hline 12 & Guggulutiktaka taila & 3 & 0.7 \\
\hline \multicolumn{2}{|c|}{ Total } & 406 & 100.0 \\
\hline
\end{tabular}

Among 474 Niruha Vasti done, taila was used in 406 Vasti. In that, 218 were done added with Sahacharadi taila; 98 were done using Dhanvantaram taila; 24 were done with Pippalyadi anuvasana taila; 18 were done with Madhuyashtyadi taila. In 12 Vasti, Tila taila was used; 11 were done with Mahanarayana taila; 7 were done using Satahvadi taila; 5 were done with Karpasasthyadi taila; 4 were done with Sinduvara eranda taila; 3 each were done using, Panchamla taila, Chinchadi taila and Guggulutiktaka taila respectively (table 7).

Table 8. Distribution of major Vasti in respect to LBP pathology

\begin{tabular}{|c|c|c|c|c|c|c|c|}
\hline Vasti & $\begin{array}{c}\text { Lumbar } \\
\text { spondylosis }+ \\
\text { IVDP }\end{array}$ & IVDP & $\begin{array}{c}\text { Lumbar } \\
\text { spondylosis }\end{array}$ & $\begin{array}{c}\text { Spinal canal } \\
\text { stenosis }\end{array}$ & $\begin{array}{c}\text { Facet } \\
\text { arthropathy }\end{array}$ & $\begin{array}{l}\text { Spondylo } \\
\text { listhesis }\end{array}$ & Sacralization \\
\hline & $\begin{array}{c}\text { Count } \\
(\%)\end{array}$ & $\begin{array}{l}\text { Count } \\
(\%)\end{array}$ & $\begin{array}{c}\text { Count } \\
(\%)\end{array}$ & $\begin{array}{c}\text { Count } \\
(\%)\end{array}$ & $\begin{array}{c}\text { Count } \\
(\%)\end{array}$ & $\begin{array}{c}\text { Count } \\
(\%)\end{array}$ & $\begin{array}{c}\text { Count } \\
(\%)\end{array}$ \\
\hline Erandamuladi & $\begin{array}{c}5 \\
(11.1)\end{array}$ & $\begin{array}{c}7 \\
(11.3)\end{array}$ & $\begin{array}{c}3 \\
(18.8)\end{array}$ & & & & \\
\hline Grdhrasihara & $\begin{array}{c}5 \\
(11.1)\end{array}$ & $\begin{array}{c}6 \\
(9.7)\end{array}$ & $\begin{array}{c}1 \\
(6.3)\end{array}$ & $\begin{array}{c}3 \\
(25.0)\end{array}$ & & & \\
\hline Kshira Vasti & $\begin{array}{c}6 \\
(13.3)\end{array}$ & $\begin{array}{c}5 \\
(8.1)\end{array}$ & $\begin{array}{c}3 \\
(18.8)\end{array}$ & $\begin{array}{c}1 \\
(8.3)\end{array}$ & & & $\begin{array}{c}1 \\
(20.0)\end{array}$ \\
\hline Madhutailika & $\begin{array}{c}10 \\
(12.2)\end{array}$ & $\begin{array}{c}13 \\
(21.0)\end{array}$ & $\begin{array}{c}4 \\
(25.0)\end{array}$ & $\begin{array}{c}3 \\
(25.0)\end{array}$ & $\begin{array}{c}1 \\
(20.0)\end{array}$ & $\begin{array}{c}8 \\
(53.3)\end{array}$ & $\begin{array}{c}3 \\
(60.0)\end{array}$ \\
\hline Ruksha Vasti & $\begin{array}{c}2 \\
(4.4)\end{array}$ & $\begin{array}{c}11 \\
(17.7)\end{array}$ & $\begin{array}{c}2 \\
(12.5)\end{array}$ & $\begin{array}{c}2 \\
(16.7)\end{array}$ & $\begin{array}{c}2 \\
(40.0)\end{array}$ & $\begin{array}{c}4 \\
(26.7)\end{array}$ & $\begin{array}{c}1 \\
(20.0)\end{array}$ \\
\hline Vaitarana Vasti & $\begin{array}{c}17 \\
(37.8)\end{array}$ & $\begin{array}{c}20 \\
(32.3)\end{array}$ & $\begin{array}{c}3 \\
(18.8)\end{array}$ & $\begin{array}{c}3 \\
(25.0)\end{array}$ & $\begin{array}{c}2 \\
(40.0)\end{array}$ & $\begin{array}{c}3 \\
(20.0)\end{array}$ & \\
\hline Total & $\begin{array}{c}\mathbf{4 5} \\
(100.0)\end{array}$ & $\begin{array}{c}\mathbf{6 2} \\
(100.0)\end{array}$ & $\begin{array}{c}16 \\
(100.0)\end{array}$ & $\begin{array}{c}12 \\
(100.0)\end{array}$ & $\begin{array}{c}\mathbf{5} \\
(100.0)\end{array}$ & $\begin{array}{c}15 \\
(100.0)\end{array}$ & $\begin{array}{c}\mathbf{5} \\
(100.0)\end{array}$ \\
\hline
\end{tabular}

Among participants presented as IVDP+ Lumbar spondylosis, $37.8 \%$ had done Vaitarana Vasti, $13.3 \%$ had Kshira Vasti, 12.2\% had Madhutailika Vasti, $11.1 \%$ each had Erandamuladi Vasti and Grdhrasihara Vasti respectively and 4.4\% had done Ruksha Vasti.

In participants with IVDP, $32.3 \%$ were done Vaitarana Vasti, 21\% had Madhutailika Vasti done and Ruksha Vasti was done in 17.7\%. Erandamuladi Vasti was done in $11.3 \%$, Grdhrasihara Vasti in $9.7 \%$ and Kshira Vasti in $8.1 \%$ participants presented with IVDP.

The participants presented with Lumbar spondylosis had Madhutailika Vasti in 25\%, Erandamuladi Vasti, Kshira Vasti and Vaitarana Vasti were done in $18.8 \%$ each, 12.5\% had Ruksha Vasti and in 6.3\% Kshira Vasti was done. Among the participants presented with Spinal canal stenosis, 25\% each had Grdhrasihara Vasti, Madhutailika Vasti and Vaitarana Vasti respectively; $16.7 \%$ were done Ruksha Vasti and in $8.3 \%$ Kshira Vasti was done.

Vaitarana Vasti (40\%) and Ruksha Vasti (40\%) was done among the majority of participants with Facet arthropathy. In $20 \%$ Madhutailika Vasti also done.

Madhutailika Vasti was done in the majority (53.3\%) of Spondylolisthesis participants. Ruksha Vasti (26.7\%) and Vaitarana Vasti $(20 \%)$ are the other Vasti done among Spondylolisthesis participants.
It was noted that in Sacralization also the major Vasti done was Madhutailika Vasti (60\%); and 20\% each had done Ruksha Vasti and Kshira Vasti (table 8).

\section{Table 9. Other Procedure during Niruha}

\begin{tabular}{|c|c|c|}
\hline Procedure & Frequency & Percent \\
\hline Without any other & 355 & 74.9 \\
\hline Procedure & 119 & 25.1 \\
\hline With other procedure & 474 & 100.0 \\
\hline Total & $474 \%$ & \\
\hline
\end{tabular}

Among 474 Vasti done, $74.9 \%$ had no other procedure on the same day of Vasti; and $25.1 \%$ had some other procedures on the same day of Niruha. Snigdha sveda, Ruksha sveda, udvartana, Kati vasti etc. are the procedures done along with Niruha (table 9).

\section{Discussion}

The present study was planned to document clinical practices of Niruha Vasti in LBP participants admitted in VPSV Ayurveda College Hospital during 2018. A total of 141 participants and the details of their Vasti procedure were observed and analysed. Perhaps this was an odd study as most of the researches in Panchakarma are focused on testing the efficacy of various Vasti. The study has helped to delineate the peculiarities of Niruha Vasti administered in LBP.

In this study, it was observed that the majority of Vasti are not done in any particular pattern of Karma 
Vasti, Kala Vasti or Yoga Vasti as explained in the text. According to a survey done by Abhilash Krishnan et al, $90 \%$ of the participants reported doing the Yoga Vasti pattern, 12\% doing Karma Vasti and 19\% practicing Kala Vasti (8). The observation of the current study does not match with that of the survey. The setting of the survey was across Kerala and it was based on the general practices of Vasti irrespective of disease and irrespective of any time frame. But the study setting of the present study was limited to VPSV Ayurveda College Hospital Kottakkal and Niruha done in LBP, during the year of 2018 only. It is also clear that it need not be fixed to any pattern, moreover, it should be specific to the case. This freedom has been left to the physician hence, the trend showed in the current study is not a strange observation, rather it supports the view of personalized treatment.

It was quite interesting to note that about 16 different types of Niruha are being used in LBP. A number of factors may influence the selection of Vasti. Dosha predominance of the participant will be taken while selecting the Vasti. Pathological variations are another factor to decide Niruha. As the pharmacological actions of Niruha include various aspects like Pachana, Brmhana, Utklesana etc. Vasti may be selected accordingly. In short, it is the logic of physician by which any specific Vasti is selected in a given condition. The present study shows that Vasti is selected with due care.

Vaitarana Vasti was the most prescribed Vasti $(22.6 \%)$ in LBP followed by Madhutailika Vasti (17.7\%), Kshira Vasti (14.6\%), Ruksha Vasti (13.5\%), Erandamuladi Vasti (9.9\%), and Grdhrasihara Vasti (9.5\%). Apart from these, 3.8\% Kshira vaitarana Vasti, $3.6 \%$ Mustadi yapana Vasti and 2.1\% Dvigunaprasrta Vasti were also used. Erandamuladi yapana Vasti, Manchishtadi kshara Vasti, Udavartahara Vasti, Doshahara Vasti, Kledahara Vasti, Kshara Vasti and Yapana Vasti are also seems to be prescribed in very few cases. Among the above said formulations, the effect of Vaitarana Vasti, Madhutailika Vasti, Erandamuladi Vasti, Mustadi yapana Vasti, Vrshadi Vasti (Grdhrasihara Vasti) and Erandamuladi yapana Vasti in LBP have already been studied (9-16). Yapana Vasti has indication in LBP related symptoms, but no research works were yet done (17-19).

No direct references are available for Ruksha Vasti in LBP and no study was done with Ruksha Vasti in LBP patients. But it is practiced by physicians in a number of cases. This reveals that the selection of formulation for Vasti is based on their clinical experiences and well-reasoned by their logical thinking. Such experiences should be put into research to validate their significance. Similarly, no previous research works available to substantiate the effect of Kshara Vasti in LBP. Kshara Vasti is indicated for Vidsamga, Udavarta, Gulma etc. (20). It is evident that there should be involvement Apana in all these conditions and the site of vitiation is Pakvasaya. In Katigraha also, the origin of aggravation of Dosha is same and hence, the indication is reasonable.
Manchishtadi kshara Vasti has been evolved from clinical experiences. Kshara Vasti is mentioned by Cakradatta and Manchishtadi kvatha is mentioned in Sarngadhara Samhita ([20, 21). Based on these, effect of Manchishtadi kshara Vasti in peripheral arterial disease has been studied (22). But no previous research works were available to prove the efficacy of Manchishtadi kshara Vasti in LBP patients. As far as Ayurveda is concerned, practices are established by adopting predominantly the experiences of skilled physicians and rest from the observations of studies.

In the 174 Vasti schedules, 84 were done as the last treatment and 74 were placed in the middle of total treatment course and 16 Vasti schedules were done in the starting. Vasti has got the multidimensional therapeutic effect and it can do Brmhana, Sodhana, Samana, Rasayana etc. As per the basic treatment protocol purification always follow preparatory procedures and it was placed at the end of a treatment schedule. In conditions where post purificatory treatments are necessary as in the case of remnant Dosha or post procedural exhaustion exists, more treatments followed the administration of Niruha.

In participants where Vasti is planned as the first line of the treatment, Vaitarana Vasti and Ruksha Vasti were usually selected. As a rule, the initial stage of a disease may have association Kaphal Ama, so Vaitarana Vastil Ruksha Vasti will be helpful in the elimination of vitiated complex lodged in Pakvasaya. Vasti is the major treatment for Vata. Repeated administration of Sneha and Sveda followed by either Virechana or Vasti is the rule of management. Hence, Vasti may be placed in between them. When the purpose of Vasti is to produce Brmhana, Samana or Rasayana it is also scheduled as the last. Madhutailika Vasti, Kshira Vasti and Grdhrasihara Vasti are seen at the end of treatment.

The different types of Vasti and change in its contents or dose pattern, selection of Taila and Ghrta in Vasti etc., mostly depends on the logic of the physician and the need of patient. Even though Gomutra is the content mentioned by different Acharya for Vaitarana Vasti, Dhanyamla was used in the majority of cases. In Grdhrasihara Vasti and Erandamuladi Vasti also Dhanyamla was prescribed instead of Gomutra for a few patients. Scarcity in obtaining fresh Gomutra may be one reason for choosing Dhanyamla. Aswani P S et al, reported that since Gomutra is very much Ruksha despite this, in clinical practice Dhanyamla is seemed to be used which is neither too Tikshna nor too Mrdu and is indicated for Asthapana (23). The experts in the field opine that Gomutra can be avoided because of the risk of leptospiral infection and Dhanyamla can be safely used (24).

Even though it is discussed that for the purpose of Sodhana rather than medicated Taila, the use of Tila taila sufficient, the data obtained shows majority of Niruha were done using medicated Taila. Among the 406 Niruha which used Taila, 53.7\% were done using Sahacharadi taila. The most used Taila in Erandamuladi Vasti, Vaitarana Vasti and Grdhrasihara Vasti was Sahacharadi taila. Sahacharadi taila has an 
affinity towards the diseases of Adhakaya that may be the reason for selection of Sahacharadi taila by a majority of the physician. In Madhutailika Vasti and Kshira Vasti, Dhanvantaram taila was used mainly. Only 3\% used Tila taila. A survey study among physicians of Kerala about the practice of Asthapana and Anuvasana Vasti reported that $87 \%$ of participants using Taila/ Ghrta specific to diseases rather than Tila taila (8). On the contrary, while using Ghrta, plain ghee was mostly used $(40.7 \%)$ in the current study. The study done by Mohammed Imthiyas et al, with plain ghee and medicated ghee for Sodhananga snehapana also proved the effect of plain ghee for the purpose (25). In this study, it was observed that Vaitarana Vasti was prescribed in the majority $(70.1 \%)$ cases of IVDP. Madhutailika Vasti was prescribed in sacralization $(60 \%)$ and spondylolisthesis $(53.3 \%)$. There were no previous data available about the influence LBP pathology in selection Vasti. Further studies are needed to prove the association.

Most of the Vasti (74.9\%) were done without any concomitant procedure. While administering a Sodhana process it is not fair to undergo any other procedure, rather rest is advised on the day. Of course, while administering Vasti with lesser dose and Vasti other than Sodhana are practiced, procedures with similar effects can be advised along with.

There are very little or no studies showing the status of our current practice and preparation of a profile or characteristics of practice have ever become an objective of any study. Observational studies of this pattern can definitely help to find out thrust areas of research and fix the priority of our research problems. Thus, the current study becomes important and unique among the current Ayurvedic research field. Overall, the study strengthens the concept that the medicine or treatment should be selected considering the stage of the disease, involvement of Dosha and pathology of the disease. Patient characteristics and severity of the disease can also influence the selection. The observations regarding the variation of Vasti in different pathologies and selection of oil in Niruha should be further investigated through clinical trials. It is also noteworthy that different recipe is used for Vasti like Ruksha Vasti and Erandamuladi yapana Vasti, a comparative evaluation of these formulations will be useful to find out the best formulation. The efficacy of new formulations needs to be further evaluated.

\section{Conclusion}

The results of the current study indicate that there is a high range of types and formulations of Vasti practicing in LBP, the selection of which is influenced by the pathology, state of Dosha and various other factors. Vaitarana Vasti, Madhutailika Vasti, Kshira Vasti, Ruksha Vasti, Erandamuladi Vasti and Grdhrasihara Vasti are the major Vasti prescribed in LBP patients. Mustadi yapana Vasti, Dvigunaprasrta Vasti, Erandamuladi yapana Vasti, Manchishtadi kshara Vasti, Udavartahara Vasti, Doshahara Vasti, Kledahara Vasti, Kshara Vasti and Yapana Vasti are also prescribed for LBP. Vaitarana Vasti is mostly adopted in the management of IVDP and physicians do not stick on to the classical patterns of Vasti kalpa while managing LBP.

\section{Conflict of interest}

Nil

\section{Reference}

1. Sreekumar T. Aștāngahrdaya Vāgbhața Sūtrastāna (Trans, comme English). $1^{\text {st }}$ ed. Mannuthy: Harisree Publication; 2007; 2: p.83.19/1.

2. Hart LG, Deyo RA, Cherkin DC. Physician office visits for low back pain. Frequency, clinical evaluation, and treatment patterns from a U.S. national survey, Spine. [PubMed] [Internet]. 1995 Jan 1; 20(1):11-9 [cited 2017 Apr 6].

3. Stephanie G Wheeler, Joyce E Wipf, Thomas O Staiger. Evaluation of low back pain in adults [Internet]. 2017 Mar [cited 2017 Apr 6].

4. Nicholas A Boon, Nicki R Colledge, Brain R Walker. Davidson's principles and practices of medicine. 20 $0^{\text {th }}$ ed. Churchil and Livingstone Elsevier Limited; 2006 p.1083.Available from: http://www.uptodate.com/contents/evaluation-oflow-back-pain-in-adults

5. Sidhinandan miśra. Bhishajya Ratnavali of Kaviraj Govind Das Sen (Siddhiprada, comme, Hindi) Varanasi: Chaukhambha Surbharathi Prakashan; 2007; 1:p.518.26/4.

6. Gangasahaya pandeya. Charaka Samhita of Agnivesa (AyurvedaDipika, Chakrapanidatta, comme, Sanskrit; Vidyothini, Kasinatha sastri, comme, Hindi) Varanasi: Chaukhambha Surbharathi Prakashan; 2007; 1:p.269.20/11.

7. Bhishagaacaarya Haris'aastri Paraad'akar Vaidya, editor. Ashtanga Hrdaya of Vāgbhața (Sarvanga sundara, Arunadatta; Ayurveda Rasayana, Hemadri: comme, Sanskrit) Varanasi: Chaukhambha Surbharathi Prakashan; 2011; p.431. Nidana sthana, $15 / 7,8$.

8. Abhilash Krishnan V K, Laila A.S. Practices of asthapana and anuvasana vasti by ayurveda practitioners in kerala; [MD Dissertation] Thiruvananthapuram; 2018

9. Sasikumar. A Study on Low back ache and its Management with Vaitarana vasti [MD Dissertation]. Thiruvananthapuram: Kerala Unversity; 1991.

10. Mousumi Manohar P A. Validation of samyak nirūha lakshana with respect to mādhutailika vasti in kateegraha. [MD Dissertation]. Kottakkal, 2012. Dissertation

11. Krishnakumar N. Clinical study on the effect of ksheera Vaitharana vasti in the management of grdhrasi w.s.r to sciatica.Anciant Science of life, 2013; 34(s2): p.38.

12. Bhatt Malini R. A clinical study on the role of Erandamūlādi Vasti in the management of Kateegraha [MD Dissertation]. Jamnagar: Gujarat Ayurveda University; 1997.

13. Nesari Manoj. The study on the role of Amrtha Bhallathaka and Rājayāpana vasti in the 
management of kateeśula with reference to spinal degenerative disease [MD Dissertation]. Jamnagar: Gujarat Ayurveda University; 1991.

14. Aswani.P.S, A.S.Lila. Clinical evaluation of Vrshadi Vasti in Grdhrasi. International Journal of Ayurveda and Pharma Research, Oct 2017; 5(10): p:41.

15. KP Damayanthie Fernando, Anup B Thakar, Vageesha Datta Shukla. Clinical efficacy of Eranda Muladi Yapana Basti in the management of Kati Graha (Lumbar spondylosis). Ayu journal, 2013; 34(1): p.36-41.

16. Salma Shirin. Evaluation of efficacy of Kșeera Vasti and Mātra vasti in Grdhrasi - A Comparative Clinical Trial [MD Dissertation]. Banglore: Rajive Gandhi University of Health sciences; 2010.

17. Pt. Bhishagacharya Harishastri Paradkar Vaidya, editor. Așțānga Hṛdayam composed by Vāgbhața with commentaries Sarvāngasundara and Āyurvedarasāyana. 6th ed. Varanasi: Chowkhambha Krishnadas Academy, 2006. Kalpasthana 4/20 p: 349. Edited Book

18. Yadavji Trikamji Aacaarya, editor. Caraka saṃhita by Agniveśa with the Aayurveda Deepika Comme. 5th ed. Varanasi: Chaukhamba Sanskrit Sansthan, 2001. Siddhistaana 12/50 p; 750 Edited Book.

19. K.H.Krshnamoorthy, P.V.Sarma, editor. Bhela Samhitha, text with English translation, comme and critical notes. 2nd ed. Varanasi: Chaukhamba Sanskrit Sansthan, 2008.Sidhisthana 8/65 p: 571 Edited book.

20. Cheppad. K. Achutha warrier, editor. Chakradattam with Goodartha Deepika commentory of Chakrapanidatta, 27th edition, S.T. Reddiar and sons, Kollam, 2010 pg. 528.

21. Bramhanand Tripathi editor. Sharangdhara Samhita of Sharangdhara, Chaukhamba Surbharti Prakashan, Varanasi, 2007 pg. 153

22. Chougule Paresh, Rao Niranjan, Shreekanth U. Manjishthadi kshara basti in the management of peripheral arterial disease a case study. International Ayurvedic Medical Journal. 2015 September; 3(9):2935-2938

23. Aswani $P$ S et al. Vaitarana Vasti - A Conceptual Study. Research Journal of Pharmacy and Technology. 2018 March; 10 (1):56-58

24. Vasudevan nmboodiri M.R, Mahadevan.L, Jayadeep.S. Principles and practices of Vasti. 1st $^{\text {st }}$ ed. Kanyakumari: Sarada mahadeva Iyer ayurvedic educational and charitable trust. 2014. p 261

25. Mohammed Imthiyas I, Manojkumar A K. A randomized clinical trial to assess the samyaksnigdha lakshana obtained by plain ghee against thikthaka ghrtha in psoriasis. (MD Dissertation) Kottakkal, 2012. 